\author{
KATARZYNA PAPAJA
}

Uniwersytet Śląski

\title{
Exploring the Use of L1 in CLIL
}

ABSTRACT. There have always been contradicting views about whether to use the mother tongue in the foreign language classroom. The issue this paper is going to examine in more detail is the use as well as the purpose of the Polish language used in selected Content and Language Integrated Learning classrooms.

\section{INTRODUCTION}

Recent years have seen a renewed interest in Content and Language Integrated Learning (CLIL). The theoretical background goes back to the middle of the last century. Content and Language Integrated Learning (CLIL) involves integration of language teaching into the learning of other subjects i.e. a language and a subject are learnt simultaneously (Lange 2001).

"Content and language integrated learning (CLIL) is a generic term and refers to any educational situation in which an additional language and therefore not the most widely used language of the environment is used for the teaching and learning of subjects other than the language itself" (Marsh/Lange, 2000, iii).

According to Wolff (Wolff, 2005), there are at least three points which are important in the context of this general definition:

1. CLIL must not be regarded simply as an approach to language teaching and learning; it is concerned both with content and language.

2. Within a CLIL framework content and language are learnt in integration. The two subjects - a language and a content subject - are related to each other and dealt with as a whole.

3. In CLIL another language is used to teach and learn content subjects, i.e. it is the medium of instruction. Language is both content and medium in the CLIL classroom. 
CLIL always involves dual-focused aims: in a CLIL class, attention is simultaneously given to both topic and language. CLIL is a generic term which covers some 20 or more educational approaches. Although these differ in terminology, they share certain common features. The main characteristic feature of CLIL as listed by Marsh (2000), a leading expert on CLIL, is curricular integration. The subject matter and the foreign language are developed simultaneously and gradually, depending on the age of students and other variables. "From what we know now about content subject learning in a foreign language we can conclude that learners learn faster and are more motivated than those in traditional content subject classrooms. It has also been shown that learners look at content from a different and broader perspective when it is taught in another language" (Wolff 2005).

One interesting observation with respect to content learning in CLIL should be mentioned here, namely autonomy. CLIL classrooms frequently mean that learners cannot rely on single sources for the purposes of a given course. What is more, "the learners have to develop their analytical skills, their reflective skills, their hypothesizing skills, and all that encourage them to take greater risks in terms of their own linguistic confidence" (Hall-Halley/Austin 2004).

The problem worthy of consideration is the use of L1 in CLIL, especially the possibility of completely eliminating L1 from CLIL. The purpose of this article is to find out whether the students as well as the teachers use the Polish language during their lessons in geography, biology, mathematics, and physics conducted in English, as well as the specific circumstances in which Polish is used, as well as the purpose for which Polish is used in selected CLIL classrooms.

\section{THE AIM}

The aim of my study was to find out when and how the students as well as the teachers use the Polish language during lessons such as geography, biology, physics and maths conducted in English. The pilot study was conducted in one of the best secondary schools in Kraków, the $1^{\text {st }}$ Secondary School. Two bilingual classes were observed: 1G - students at the age of 16-17 and class $2 \mathrm{G}$ - students at the age of $17-18$. The bilingual syllabus concerning the subjects mentioned above was based on the National Polish Curriculum for Secondary Schools and covered the same topics as the monolingual one. Four teachers of these classes were observed, all of whom are specialists in their particular subject (e.g. geography or maths), but none of whom has a degree in English or other language-related studies. Most of them have Language Certificates in English and two of them have studied abroad. 


\section{THE METHOD}

The method used for my study was observation. This method has been considered a major data collection tool in qualitative research. The main advantages of using observations for collecting data are that they allow the study of a phenomenon at close range with many of the contextual variables present, a feature which is very important in studying language behaviours. I took part in the lessons and observed the students as well as the teachers. 28 lessons were observed including 7 lessons of geography ( 3 in class $1 \mathrm{G}$ and 4 in class 2G), 7 lessons of biology ( 3 in class $1 G$ and 4 in class 2G), 7 lessons of maths ( 3 in class $1 G$ and 4 in class $2 G$ ) and 7 lessons of physics ( 3 in class $1 \mathrm{G}$ and 4 in class $2 \mathrm{G}$ ). A video camera was not used as it could have had more influence on the subjects' behaviour. According to Selinger the presence of a video camera makes people behave unnaturally (Selinger 1989). Two separate observation sheets were prepared and they were divided into four parts: the stage of the lesson (e.g. revision, brainstorming, practice etc. concerning the content subjects), the use of L1 (content - when?), the use of L1 (form - how?) and my own comments. In the first part - the stage of the lesson, I was observing in which parts of the lesson the Polish language was often used by the students as well as by the teachers. In the next part - the use of L1 in context, I concentrated on the situations in which the Polish language was used by the students and by the teachers - while giving lectures by the teachers or when sorting out certain tasks by the students, etc. In the third part I concentrated on the form in which the Polish language was used, in other words, on the Polish discourse in the classroom - verbal expressions in speech of the students as well as the teachers. The last part of my observation sheet was devoted to my own comments. In this part certain behaviours of the students as well as the teachers were registered and analysed, e.g. the fact that the students speak Polish among themselves during the lesson. Each observation sheet had such additional information as subject taught geography, biology, physics or maths, the number of students present, the teacher and the date.

\section{THE MATERIALS USED}

There are no suitable course books in English for the particular subjects which would satisfy the requirements of the Polish National Curriculum. Handouts with specialised vocabulary translated from English into Polish are distributed among the students (geography, biology). The students are asked to work with Polish books or articles and to translate certain parts from Polish into English (physics and geography). The students are asked to 
solve certain problems (the tasks are given in Polish) and provide the solution in English (maths). They also work with American course books which are only available during the lessons (biology).The teachers often use various visual aids - computer, video, DVD, internet, pictures and OHP.

\section{THE STUDENTS}

Although in the school in question there are not many candidates to take the courses with subjects taught in English, the classes are very big. In class $1 G$ there are 33 students and in class $2 G-29$ students. $75 \%$ of them have already passed their Cambridge Certificate in Advanced English and $60 \%$ of them are preparing for the Proficiency Exam. About $80 \%$ of students were present during the observations. The students use Polish during the lessons when a new topic is introduced, e.g. "Co to są ruchy oscylacyjne? Nie rozumiem" (geography), "Jakie są komponenty RNA? Nie dostaję tego po angielsku" (literal translation from English - I don't get it in English) (biology), "Jak to jest z tymi falami?, jeszcze raz" (physics), "Niech Pani wytłumaczy to równanie po polsku, pleeease" (mathematics). At the same time, when they ask each other for an explanation of certain terms, they also do this in Polish. Apart from that, the students often ask the teachers questions in Polish e.g."Czy urine to jest mocz?" (biology), "Czy soil to gleba?" (geography), "Triangle to stożek czy trójkąt?" (maths), "Frequency to częstotlizwość?". The students use Polish when they ask for particular information about their test or homework e.g. "Kiedy mamy test?", "32 pkt to jaka ocena?", "Czy z gleb będziemy mieli kartkówkę?"

The students use more Polish during maths and physics - during one lesson in physics, the students produced only 4 sentences in English. They were connected with the topic of the lesson but were very simple from the point of view of their construction, e.g. "The final result of this equation is 46 ", "Friction is the interaction between two surfaces", "Biomechanics is the science", "It's Newton's law, the one about the apple?" - the rest was in Polish. Summing up, on average, about $80 \%$ of the students' utterances in one lesson were produced in Polish.

\section{THE TEACHERS}

There are four teachers who teach subjects in English. Their task is rather difficult because of the lack of adequate materials. Teachers spend hours preparing lessons and searching for suitable resources. Most of the teaching materials are taken and translated from Polish books. The teachers under 
observation usually use the Polish language while introducing the new topic "Napiszcie sobie nowy temat - komórka" «translation: Write down a new topic - the cell". In addition to it, they often give a short lecture in English and then they translate it into Polish. All of them use Polish when introducing new terms e.g. Velocity to prędkość (physics), tremor to drganie (geography), Cortex to kora (biology), Equation to równanie (maths) etc. Apart from that, they often use Polish when asked for an explanation e.g. "Drganie to pewnego rodzaju ruch, który ma miejsce podczas wstępnej fazy trzęsienia ziemi" (geography). The teachers often prompt questions in English and ask students to answer them in English. However, if the students have problems they give clues in Polish eg. "Could you give me an example of Doppler's effect, no efekt Dopplera, to było na poprzedniej lekcji?" (physics), "How much urine do you think we produce? Ile moczu produkujemy dziennie, jak myślisz?" (biology), "Come to the blackboard and draw a volcano, no wulkan narysuj" (geography), "Come to the blackboard, draw the triangle and explain the solution, OK, zapomnij o angielskim, wszyscy mają to zrozumieć" (maths). The teachers who teach maths and physics use more Polish during the lesson.

While trying to control the class the teachers use Polish only, e.g. "Pracujcie w grupach i bądźcie cicho", "Z czego jesteście tak zadowoleni? Daj Wam Bozia zdrowie", "Wy to jesteście zorganizowani, chyba omdleję" etc. Summing up, on the average, the teachers use more than $70 \%$ of Polish during one lesson.

\section{THE RESULTS OF THE STUDY}

There has been an observable difference between the behaviour of students from class $1 G$ and $2 G$. The students from the first class seem to be very shy - I noticed that they do not feel as confident in using English as the students from class 2G. Questions are often prompted in Polish, especially if they do not understand something. It usually happens when a new topic is introduced. Apart from that, the students ask the teachers in Polish when they want to check if they understand a certain term properly, which also suggests the lack of confidence. They also use Polish when they need some specific information about their test results or homework - they are probably afraid that they may misunderstand some important information. What is more, the students use Polish more often during mathematics and physics. It is probably because the subjects are difficult themselves even in Polish.

As it has already been mentioned, the teachers have a very difficult task to face. I interviewed all of them and they all seem to have one problem - the lack of materials. As a result, they have to spend hours preparing lessons and search- 
ing for sources. They usually use Polish while introducing a new topic and new terms. They translate the terms from English into Polish to help the students understand everything exactly. The teachers pay attention to students' understanding. They often give explanations and clues in Polish. When being asked a question in Polish, they also provide answers in Polish, which seems to be logical since people tend to answer questions in the same language as the question.

As it has already been mentioned, the teachers of mathematics and physics tend to use more Polish during the lesson. I asked the teachers why they use so much Polish during their lessons. Their answer was that the subjects were very difficult themselves even in Polish and certain formulas had to be translated into Polish. Another thing is that the students have linguistic talents rather than the mathematical ones. One teacher said: "My subject is black magic to most of them, I have to use Polish because otherwise the students will not be able to understand anything". The last point is the use of every day language. While trying to control the class the teachers use Polish. The message in Polish reaches the students faster and the result was visible e.g. the students were quiet immediately after the teacher's remark.

\section{CONCLUSION}

On the basis of the study, it can be said that the use of L1 in CLIL has been quite extensive. According to Marsh (2001), the first language should be used for introducing new terms. Here, however, both the students as well as the teachers use the Polish language for more purposes: as a medium of instruction, including explanation of certain terms, as well as to regulate and organize classroom activities and to talk about the course itself.

Both the students and the teachers seem to be very eager to use English. However, the students still seem to lack confidence in using it for talking about the subject matter, for example about genes. This may be due to their previous experience - most of them have never learnt any subject in a foreign language. On the other hand, due to financial reasons, the teachers lack proper materials which makes their work very difficult.

In my opinion, there is a chance that the use of L1 in CLIL will decrease within the next few years and students will feel more confident while learning subjects in foreign languages. In my $\mathrm{PhD}$, I would like to concentrate not only on the use of L1 in CLIL but on the language development of the students and their relationship with the teachers. By language development I mean the development of receptive skills (reading and listening comprehension) and productive skills (writing and speaking) in CLIL. In addition to it, I would also like to concentrate on the relationship between the teacher and the students which, I find relevant in the CLIL classroom. 


\section{REFERENCES}

Hall-Halley M./Austin T.Y., 2004, Content-based Second Language Teaching and Learning: An Interactive Approach. Allyn \& Bacon, UK.

Krashen, S., 1981, Second Language Acquisition and Second Language Learning. Oxford University Press: Oxford.

Marsh, D./Marshland, B./Maljers A., 1998, Future Scenarios in CLIL., Continuing Education Centre, University of Jyväskylä.

Marsh, D./Marshland, B., (eds.), 1999, CLIL Initiatives for the Millennium. University of Jyväskylä.

Marsh, D./Maljers, A./Hartiala, A-K., 2001, Profiling European CLIL Classrooms - Languages Open Doors. University of Jyväskylä.

Marsh, D./Lange, G., 2000, Using languages to learn and learning to use languages, University of Jyväskyla.

Seliger, Herbert W., (1996). Primary language attrition in the context of bilingualism. In: W.C. Ritchie/T.K. Bhatia (eds.), Handbook of second language acquisition. San Diego: Academic Press.

Wolff, D., 2003, Content and language integrated learning: a framework for the development of learner autonomy. In: D. Little/J. Ridley/E. Ushioda (eds.), Learner Autonomy in the Foreign Language Classroom: Teacher, Learner, Curriculum and Assessment. Dublin: Authentik: 211-222.

Wolff, D., 2004, Integrating language and content in the language classroom: Are transfer of knowledge and of language ensured?, Proceedings of the GERAS, Paris: GERAS.

Wolff, D., 2005, Content and Language Integrated Learning (a paper from $18^{\text {th }}$ International Conference on Foreign/Second Language Acquisition, Szczyrk, Poland, May 2006)

http://www.tieclil.org 